Jpn. J. Med. Sci. Biol., 48, 193 - 198, 1995.

Short Communication

\title{
STUDY OF HEMAGGLUTINATING PROPERTY OF ENTERO- INVASIVE ESCHERICHIA COLI FROM VARIOUS GEOGRAPHICAL LOCATIONS
}

\author{
Shakhawat Hossain BHUIYAN, Hasibur RAHMAN and Khaleda HAIDER1 \\ Department of Microbiology, University of Dhaka, Dhaka-1000 and International \\ Center for Diarrheal Disease Research, GPO Box-128, Dhaka-1000, Bangladesh
}

(Received April 17, 1995. Accepted August 8, 1995)

SUMMARY: Thirty-four strains of enteroinvasive Escherichia coli (EIEC) were examined for their ability to agglutinate erythrocytes from different animal species. All strains cultured in Casamino acid-yeast extract medium in the presence of $1 \mathrm{mM} \mathrm{CaCl} 2$ at $37 \mathrm{C}$ for $16-22 \mathrm{hr}$ induced maximal expression of hemagglutination (HA) of broad spectrum erythrocytes. The strongest HA was observed with guinea-pig erythrocytes followed by human ( $O$ type), rat, mouse, rabbit and sheep erythrocytes. All the strains failed to agglutinate chicken erythrocytes. HA was resistant to D-mannose, D-glucose, D-galactose, L-fucose, and D-fructose. Also HA was resistant to ethylene diamine tetraacetic acid (EDTA) and Na metaperiodic acid, an oxidizing agent. However, it was heat labile and completely inhibited by proteolytic enzymes such as proteinase $\mathrm{K}$ and trypsin, suggesting that the possible hemagglutinin of EIEC associated with the cell surface is a proteinaceous substance.

The ability of many enteropathogenic bacteria to adhere to the intestinal epithelium is an important factor in the pathogenesis of diarrheal diseases (1). The adherence of bacteria to the epithelial cell is widely regarded as an important prerequisite for colonization and virulence manifestation of the microorganisms (2). Enteroinvasive Escherichia coli (EIEC) includes a group of organisms which cause dysenteric enteritis similar to that caused by Shigella species. The viru- 
lence mechanisms of EIEC are similar to those of Shigella species. Like Shigella, EIEC can invade colonic epithelial cells, multiply intracellularly and induce ulceration. As in shigellosis, the infection is localized (3). Recently, Qadri et al. (4) showed that $S$. dysenteriae strains have hydrophobic cell surfaces and can agglutinate erythrocytes from different animal species (5). The adhesin molecule is a lipopolysaccharide (6). In this study, we assayed EIEC strains to characterize the hemagglutination (HA) property and the putative hemagglutinin.

A total of 34 enteroinvasive $E$. coli strains included in the study were obtained from stools from patients with diarrhea in Bangladesh $(n=2)$, Hungary $(n=2)$, Australia $(n=2)$ and Thailand $(n=28)$. The strains from Thailand and Hungary were kindly provided by Dr. David Taylor, Department of Bacterial Diseases, Walter Reed Army Institute of Research, Washington, D. C., USA, and Armed Forces Research Institute of Medical Sciences, Thailand. These strains were identified by standard biochemical tests (7). Shigella dysenteriae type I strain 14731 and nonpathogenic E. coli (strain 36000) were used as positive and negative controls, respectively. All strains of EIEC and S. dysenteriae I (14731) were tested for binding Congo red (4) and inducing keratoconjunctivitis in the guinea-pig eye (8). The strains stored at $-70 \mathrm{C}$ were subcultured and grown in Trypticase soy broth (TSB), nutrient medium, minimal medium, colonization factor antigen (CFA) medium, Casamino acid-yeast extract (CYE) medium and CYE with $1 \mathrm{mM} \mathrm{CaCl}$. The cultures were incubated at $37 \mathrm{C}$ for $16-22 \mathrm{hr}$ with shaking $(250 \mathrm{rpm})$ and the pellets collected by centrifugation at $1,500 \mathrm{rpm}$ for $10 \mathrm{~min}$ were tested for hemagglutination activities. HA was performed at room temperature on glass slides with $20 \mu \mathrm{l}$ of a bacterial suspension $(1 \times 1010 \mathrm{CFU} / \mathrm{ml})$ mixed with $20 \mu \mathrm{l}$ of $2 \%$ guinea-pig erythrocytes according to the method of Qadri et al (5). The slide was gently rocked between the thumb and forefinger and observed for visible agglutination. A $4+$ reaction was recorded when agglutination occurred within $30 \mathrm{sec}$ to $1 \mathrm{~min}$. A $3+$ reaction was recorded when agglutinination occurred within $2 \mathrm{~min}, 2+$ within $5 \mathrm{~min}$ and $1+$ within $10 \mathrm{~min}$; strains showing no HA within 10 min were considered negative. Erythrocytes from different species of animals such as the mouse, rat, rabbit, sheep, human (type 0 ), and chicken were used in HA assay. For HA inhibition, a bacterial suspension was incubated with each of different sugars (final concentration $1 \% \mathrm{w} / \mathrm{v}$ ) for $10 \mathrm{~min}$ at room temperature prior to use in the HA assay. It was also held at $56 \mathrm{C}$ for $5,10,30$ and 60 min washed with PBS and then centrifuged (5,000 rpm for $10 \mathrm{~min}$ ). The precipitate was used for HA. To determine the effect of proteolytic enzyme on HA, bacterial cell suspension was treated with each of trypsin and proteinase $\mathrm{K}$ at 2 
Table I. Patterns of HA of EIEC strains with different types of erythrocytes

\begin{tabular}{lllllllll}
\hline & & \multicolumn{7}{c}{ HA activity with erythrocytes: } \\
\cline { 3 - 8 } No. & $\begin{array}{l}\text { EIEC } \\
\text { strains }\end{array}$ & $\begin{array}{l}\text { Guinea } \\
\text { pig }\end{array}$ & Human & Rat & Chicken & Mouse & Sheep & Rabbit \\
\hline 1. & L-598-3 & $4+$ & $4+$ & $4+$ & - & $4+$ & $4+$ & $4+$ \\
2. & D-226-2 & $4+$ & $2+$ & $3+$ & - & $2+$ & $2+$ & $2+$ \\
3. & CH-162-6 & $2+$ & $2+$ & $2+$ & - & $2+$ & $2+$ & $2+$ \\
4. & D-306-6 & $4+$ & $4+$ & $4+$ & - & $4+$ & $2+$ & $2+$ \\
5. & EI-553-5 & $4+$ & $4+$ & $4+$ & - & $3+$ & $2+$ & $2+$ \\
6. & D-195-5 & $4+$ & $4+$ & $4+$ & - & $4+$ & $2+$ & $3+$ \\
7. & BH-16-1 & $2+$ & $2+$ & $2+$ & - & $2+$ & $2+$ & $2+$ \\
8. & EI-164-2 & $2+$ & $2+$ & - & - & - & - & - \\
9. & EI-234-1 & $3+$ & $2+$ & $2+$ & - & - & $2+$ & $2+$ \\
10. & D-97-8 & $3+$ & - & - & - & $2+$ & $2+$ & - \\
11. & $83057(a)$ & $4+$ & $4+$ & $4+$ & - & $4+$ & $4+$ & $4+$ \\
12. & 76699 & $4+$ & $4+$ & $4+$ & - & $4+$ & $3+$ & $3+$ \\
13. & 2 & $4+$ & $3+$ & $2+$ & - & $2+$ & $2+$ & $2+$ \\
14. & $679 C 3$ & $4+$ & $4+$ & $3+$ & - & $3+$ & $2+$ & $3+$ \\
\hline
\end{tabular}

CYE broth supplemented with $1 \mathrm{mM} \mathrm{CaCl}_{2}$ was used as a medium.

Incubation of bacteria was for $22 \mathrm{hr}$ at $37 \mathrm{C}$ with shaking.

Sources of strains: S1 No. 1-10 Thailand; 11-12 Australia; 13 Hungary; 14 Bangladesh.

$\mathrm{mg} / \mathrm{ml}$ concentration for $3 \mathrm{hr}$ at $37 \mathrm{C}$ prior to the HA assay. Cells were also treated with each of sodium metaperiodate $(2 \mathrm{mg} / \mathrm{ml})$ and EDTA $(100 \mathrm{mM})$ for $30 \mathrm{~min}$, $1 \mathrm{hr}$ and $2 \mathrm{hr}$ at $37 \mathrm{C}$ prior to the HA assay.

Of the 34 EIEC strains tested, $23(68 \%)$ showed strong $(4+)$ HA with guinea-pig erythrocytes and the other $11(32 \%)$ were weakly positive $(2+)$. When 14 strains randomly chosen (Table I) were tested, 64\% showed strong HA (4+) with guinea-pig erythrocytes, $50 \%$ with human (type 0 ), $14 \%$ with sheep, $42 \%$ with rat, and $35 \%$ with mouse erythrocytes. Several other enteropathogens such as Aeromonas hydrophila and S.dysenteriae type 1 have also been reported to 
Table II. Effects of growth media and various treatments of bacterial cells on $\mathrm{HA}$ reaction

\begin{tabular}{lc}
\hline $\begin{array}{l}\text { Culture medium or } \\
\text { agent }\end{array}$ & $\begin{array}{l}\text { HA activity with guinea- } \\
\text { pig erythrocytes }\end{array}$ \\
\hline CYE broth & $2+$ \\
CYE broth $+\mathrm{CaCl}_{2}$ & $4+$ \\
CFA broth $+\mathrm{CaCl}_{2}$ & - \\
Nutrient broth $+\mathrm{CaCl}_{2}$ & - \\
TSA $+\mathrm{CaCl}_{2}$ & - \\
TSB $+\mathrm{CaCl}_{2}$ & - \\
$\mathrm{CFA}+\mathrm{CaCl}_{2}$ & - \\
$\mathrm{CYE}+\mathrm{CaCl}_{2}$ & - \\
Enzyme $(2 \mathrm{mg} / \mathrm{ml}):$ & - \\
Trypsin & - \\
Proteinase K & \\
Chemical compound: & $4+$ \\
EDTA $(100 \mathrm{mM})$ & $4+$ \\
Na metaperiodate $(2 \mathrm{mg} / \mathrm{ml})$ & \\
\hline
\end{tabular}

$\mathrm{CaCl}_{2}$ added, $1 \mathrm{mM}$; bacterial growth, $22 \mathrm{hr}$ at $37 \mathrm{C}$ with shaking.

have similarly a broad erythrocyte spectrum for HA $(5,9)$. However, all the EIEC strains tested in this study failed to agglutinate chicken erythrocytes (Table I). The reason for this is not known but it may be speculated that as chicken erythrocytes are nucleated while other erythrocytes are anucleated, and the probable difference in the cell surface is associated in some way with this observation. Expression of the HA activity was modulated by the growth conditions of the organisms, as has been observed with $S$. dysenteriae type 1 and other diarrheagenic microorganisms (5). Like shigella, growth for 16-22 hr in CYE medium supplemented with $1 \mathrm{mM} \mathrm{CaCl}_{2}$ was required for optimal expression of $\mathrm{HA}$ activity (Table II).

HA was not inhibited by D-mannose, indicating that these strains probably possess some different sugar-combining sites that mediate the HA. Similar mannose resistance of HA has been observed in other enteropathogenic bacteria 
such as Aeromonas hydrophila (9), Campylobacter pylori (10), and this characteristic has been correlated with adherence of the organisms to the intestinal epithelial cells. The HA property of EIEC strains was sensitive to heat treatment and abolished after incubation at $56 \mathrm{C}$ for $10 \mathrm{~min}$. Agglutination failed to recur after cooling to $20 \mathrm{C}$, suggesting that $\mathrm{HA}$ by EIEC can be described as an eluting type (11) which is sensitive to heat. The HA properties of EIEC was resistant to treatment with sodium metaperiodate, an oxidizing agent or EDTA. Proteinaceous hemagglutinins are resistant to treatment with $\mathrm{Na}$ metaperiodate (12). Treatment of hemagglutinating bacteria with proteolytic enzymes such as proteinase $\mathrm{K}$ and trypsin completely abolished the HA activity. These results cumulatively suggest that the putative hemagglutinin of EIEC associated with the cell surface is a proteinaceous substance.

\section{REFERENCES}

1. Beachy, E. H. (1981): Bacterial adherence: adhesin-receptor interactions mediating the attachment of bacteria to mucosal surface. J. Infect. Dis., 143, 325-345.

2. Izhar, M., Nuchamowitz, Y. and Mirelman, D. (1982): Adherence of Shigella flexneri to guinea-pig intestinal cell is mediated by a mucosal adhesin. Infect. Immun., 35, 1110-1118.

3. Formal, S. B. and Hornick, R. B. (1987): Invasive Escherichia coli. J. Infect. Dis., 137, 641-644.

4. Qadri, F., Hossain, S. A., Ciznar, I., Haider, K., Ljungh, A., Wodstrom, T. and Sack, D. A. (1988): Congo red binding and salt aggregation as indicators of virulence in Shigella species. J. Clin. Microbiol., 26, 1343-1348.

5. Qadri, F., Haq, S. and Ciznar, I. (1989): Haemagglutinating properties of Shigella dysenteriae type 1 and other shigella species. Infect. Immun., 57, 2909-2911.

6. Qadri, F., Haq, S., Ciznar, I. and Tzipori, S. (1991): The association of haemagglutination and adhesion with lipopolysaccharide of Shigella dysenteriae serotype I. J. Med. Microbiol., 34, 259-264.

7. Ewing, W. H. (1986): Edwards and Ewing's identification of Enterobacteriacae. 4th ed., p.120-124. Elsevier Science Publishing Inc., New York.

8. Sereny, B. (1955): Exprimental Shigella keratoconjunctivitis. Microbiol. Hung., 2, 293-296.

9. Sanyal, S. C., Agarwal, R. K. and Annapurna, E. (1983): Haemagglutinating properties and fimbriation in enterotoxigenic Aeromonas hydrophila strains. Indian J. Med. Res., 78, 324-330. 
10. Emody, L., Carlson, A., Ljungh, A. and Wadstrom, T. (1988): Mannoseresistant haemagglutination by Campylobacter pylori. Scand. J. Infect. Dis., $20,353-354$.

11. Duguid, J. P., Clegg, S. and Wilson, M. I. (1979): The fimbrial and nonfimbrial haemagglutinins of Escherichia coli. J. Med. Microbiol., 12, 213227.

12. Mouton, C., Bouchard, D., Deslauriers, M. and Lamonade, L. (1989): Immunochemical identification and preliminary characterization of a non fimbrial haemagglutinating adhesion of Bacteroides gingivalis. Infect. Immun., 57, 566-573. 